\title{
GROWTH, NUTRIENT UTILIZATION AND BODY COMPOSITION OF JUVENILE BAGRID CATFISH, CHRYSICHTHYS NIGRODIGITATUS (ACTINOPTERYGII: SILURIFORMES: CLAROTEIDAE), FED DIFFERENT DIETARY CRUDE PROTEIN LEVELS
}

\author{
Morenike A. ADEWOLU ${ }^{1 *}$ and Tillmann J. BENFEY ${ }^{2}$ \\ ${ }^{1}$ Department of Fisheries, Lagos State University, Nigeria \\ ${ }^{2}$ Department of Biology, University of New Brunswick, Canada
}

Adewolu M.A., Benfey T.J. 2009. Growth, nutrient utilization and body composition of juvenile bagrid catfish, Chrysichthys nigrodigitatus (Actinopterygii: Siluriformes: Claroteidae), fed different dietary crude protein levels. Acta Ichthyol. Piscat. 39 (2): 95-101.

\begin{abstract}
Background. The African bagrid catfish, Chrysichthys nigrodigitatus (Lacepède, 1803), is an omnivorous species cultured in both fresh and brackish waters because of its good growth rate, excellent taste, and high market demand. There has been little nutritional work on this economically important species. This study was designed to determine the effects of varying dietary crude protein levels on growth, nutrient utilization and body composition of juvenile $C$. nigrodigitatus.

Materials and Methods. One hundred and twenty fish with an initial mean weight of $21.33 \pm 0.48 \mathrm{~g}$ were divided randomly among 12 tanks for triplicate groups that were fed diets containing $20 \%, 25 \%, 30 \%$, and $35 \%$ crude protein $(\mathrm{CP})$. Feed consumption and fish weight were measured biweekly for eight weeks, after which proximate composition of the fish was determined.

Results. Fish fed the $35 \% \mathrm{CP}$ diet had the best growth performance and nutrient utilization $(P<0.05)$, with a mean weight gain of $88.3 \% \pm 0.2 \%$, feed conversion ratio (FCR) of $2.60 \pm 0.12$, and protein efficiency ratio (PER) of $1.10 \pm 0.05$. The least weight gain $(32.1 \% \pm 0.9 \%)$ and poorest FCR and PER $(5.70 \pm 0.06$ and $0.87 \pm$ 0.01 , respectively) were observed in fish fed the $20 \% \mathrm{CP}$ diet. Body protein content was not affected by diet, but body lipid increased significantly $(P<0.05)$ with increasing dietary protein levels.

Conclusion. C. nigrodigitatus juveniles will grow best when fed diets containing at least $35 \% \mathrm{CP}$.
\end{abstract}

Keywords: bagrid catfish, Chrysichthys nigrodigitatus, dietary protein, nutrient utilization, growth

\section{INTRODUCTION}

The bagrid catfish, Chrysichthys nigrodigitatus (Lacepède, 1803), is an omnivorous species indigenous to Africa that is cultured in both fresh and brackish waters (Afinowi and Marioghae 1987). It has been shown to have high food conversion efficiency, with good growth and survival (Ezenwa 1982a, 1982b), as well as high quality meat and excellent taste, and hence is in great demand and highly priced (Ezenwa 1982b, Ibrahim 1988). However, little nutritional research has been carried out on this economical important species, hindering the viability of commercial production.

In determining the minimum nutrient requirements of a cultured species, protein is usually given first consideration because of its high cost and essential role for growth, tissue maintenance and reproduction. Among the catfishes, optimal dietary crude protein (CP) levels are $24 \%-37 \%$ for juvenile channel catfish Ictalurus punctatus (see: Garling and Wilson 1976; Robinson and Li 1998, 1999,
Li et al. 2000, Gibson and Gatlin 2001, Li et al. 2003, 2007, D'Abramo et al. 2008), 33\%-37\% for juvenile South American jundia catfish, Rhamdia quelen (see: Meyer and Fracalossi 2004), 35\% for juvenile African catfish, Clarias gariepinus (see: Arowosoge 1987, Omar 1996), 40\% for fingerling $(<10 \mathrm{~g})$ bagrid catfish, Chrysichthys nigrodigitatus (see: Adewolu and Fagade 1996), hybrid African catfish, Clarias gariepinus $\times$ Heterobranchus bidorsalis (see: Adebayo and Quadri 2005), and European catfish, Silurus glanis (see: Bekcan et al. 2006), and $40 \%-42 \%$ for Asian red tail catfish, Hemibagrus (Mystus) nemurus (see: Khan et al. 1993, 1996, Ng et al. 2001). The presently reported study was undertaken to determine the effects of varying dietary CP levels on the nutrient utilization and growth of juvenile Chrysichthys nigrodigitatus, with a view to determining its protein requirement.

\section{MATERIALS AND METHODS}

Fish. Juvenile bagrid catfish, Chrysichthys nigrodigitatus,

\footnotetext{
${ }^{*}$ Correspondence: Dr. Morenike A. Adewolu, Department of Fisheries, Faculty of Science, Lagos State University, P.M.B. 01 Ojo, Badagry Expressway, Lagos, Nigeria, phone: +2348030567600, e-mail: madewolu@yahoo.com
} 
were collected from Asejire Lake (Oyo State, Nigeria) and transported in an ice-chest to concrete tanks located outside the Zoology Laboratory of the University of Ibadan, Nigeria. The tanks were protected from direct sunlight by a palm-leaf roof. The fish were acclimated to the experimental conditions over a 14-day period, during which they were trained to feed on pelleted diets.

Diet Formulation and Preparation. Diets with 20\%, $25 \%, 30 \%$, and $35 \%$ CP (designated CP20, CP25, CP 30 and CP35, respectively) were formulated using Pearson's square method (Gohl 1985). The choice of feed ingredients was based on their availability, cost and protein, energy, vitamin, and mineral contents. Diet formulations and proximate compositions are presented in Table 1. Groundnut cake $(9.2 \% \mathrm{CP})$ and fish meal $(65 \% \mathrm{CP})$ served as the primary protein source in a ratio of $2.5: 1$, respectively, while maize $(9.2 \% \mathrm{CP})$ and rice bran $(8.2 \% \mathrm{CP})$ were added as the energy source in a ratio of $3: 1$, respectively. Groundnut oil served as a fatty acid and energy source while bone meal and ground oyster shell were added as mineral sources. Sodium chloride (table salt) was also added as a mineral source and for palatability. All diets were fortified with a vitamin premix to meet the requirement for catfishes (Anonymous 1976). Diet preparation was as described by $\mathrm{Ng}$ et al. (1998). All ingredients were finely ground, mixed with groundnut oil and some warm water, and then mixed thoroughly with a blender until a paste was formed. Pellets were made with an improvised pelleting device and dried to a constant weight in a Gallenkamp oven preset to $60^{\circ} \mathrm{C}$. Dried pellets were allowed to cool and were then stored in labelled dried bottles for feeding.

Feeding trial. Concrete tanks $(n=12)$, each of $100-\mathrm{L}$ capacity, were supplied with static dechlorinated tap water with a daily $50 \%$ exchange of water to maintain water quality and prevent ammonia build-up. A total of 120 juvenile catfish (mean weight of $21.33 \pm 0.48 \mathrm{~g} \mathrm{SD}$ ) were divided randomly among the tanks for four triplicate dietary treatments (10 fish/tank). Food was withheld from the fish for $24 \mathrm{~h}$ prior to starting the experiment. The fish were then fed their respective diets at $3 \%$ of total body weight per day, as recommended by Viveen et al. (1986) for catfishes, with half the daily ration fed to the fish at $0900 \mathrm{~h}$ and the other half at $1800 \mathrm{~h}$. Feeding was generally completed in 5-10 min and no uneaten food remained. Fish were reweighed biweekly and feeding rate was adjusted accordingly. Water quality was maintained within the levels recommended for catfish culture (Viveen et al. 1986). Temperature was $26.5 \pm 0.5^{\circ} \mathrm{C}, \mathrm{pH}$ was $7.5 \pm 0.1$ and dissolved oxygen was $5.0 \pm 0.5 \mathrm{mg} \cdot \mathrm{L}^{-1}$. The feeding trial lasted for 8 weeks.

Proximate Analysis. Proximate composition of the experimental diets was analyzed before commencing the experiment, while fish were analyzed at both the beginning and end of the experiment. Moisture $\left(105^{\circ} \mathrm{C}\right.$ oven, overnight), crude protein (micro-Kjeldahl method, $\mathrm{N} \times 6.25$ ), crude lipid (Soxhlet extraction), ash (muffle furnace at $550^{\circ} \mathrm{C}$ ) and crude fibre (acid/base digestion) were deter- mined using standard procedures (Anonymous 1990). Nitrogen-free extract (NFE; carbohydrate) was calculated by taking the sum of values for crude protein, crude lipid, crude fibre, and moisture, and subtracting this from 100 (Maynard et al. 1979)

Growth and nutrient utilization parameters. Growth and nutrient utilization parameters were assessed in terms of weight gain, specific growth rate (SGR), feed conversion ratio (FCR), protein intake (PI) and protein efficiency ratio (PER), using the following formulae:

$$
\text { Weight gain [\%] }=\frac{\left(W_{f}-W_{i}\right) \times 100}{W_{i}},
$$

where $W_{f}$ and $W_{i}$ represent mean final and initial weights [g], respectively

$$
\operatorname{SGR}(\% \mathrm{BW} / \text { day })=\frac{\left(\log _{e} W_{f}-\log _{e} W_{i}\right) \times 100}{T},
$$

where $T$ represents trial duration (day)

$$
\mathrm{FCR}=\frac{\mathrm{TFC}}{\left(W_{f}-W_{i}\right)},
$$

where TFC represents total amount of feed consumed [g]

$$
\begin{aligned}
& \text { PI }[\mathrm{g}]=\frac{\mathrm{TFC} \times \% \text { protein in the diet }}{100}, \\
& \text { PER }=\frac{\left(W_{f}-W_{i}\right)}{\mathrm{PI}}
\end{aligned}
$$

Statistical Analysis. Replicate values were combined after first confirming the absence of any tank effects. One way analysis of variance (ANOVA) was used to test for the effect of diet (CP level) on the various parameters measured in this study, using Microsoft STATISTICA ${ }^{\circledR}$. A p-value of 0.05 was used as the level of statistical significance.

\section{RESULTS}

There was no mortality and all fish appeared healthy throughout the 8-week experimental period. The initial weight of the fish was not significantly different among experimental groups (Table 2). Final weight, percent weight gain, specific growth rate, total feed consumed and protein intake all increased, and feed conversion ratio decreased, with increasing dietary crude protein level, with significant differences among all treatment groups for all of these parameters. Protein efficiency ratio was not significantly different among the three diets with higher crude protein levels, but all were significantly higher than for the CP20 diet. Compared to initial values, body lipid content increased and water content decreased with increasing dietary protein level, with no effect on protein content (Table 3). Although there were significant differences among diets in whole-body ash and carbohydrate contents, there was no clear relationship to dietary protein level. 


\section{DISCUSSION}

Growth, as expressed by absolute weight gain, percentage weight gain and specific growth rate, increased with increasing dietary protein level within the range of $20 \%-35 \%$ crude protein. This pattern of growth agrees with the work of Dahlgren (1979) on juvenile channel catfish; Jauncey (1982) on juvenile Mozambique tilapia, Sarotherodon mossambicus; Kim and Lall (2001) on juvenile haddock, Melanogrammus aeglefinus; Kim et al. (2002) on juvenile olive flounder, Paralichthys oli- vaceus; and Martínez-Palacios et al. (2007) on juvenile Mexican silverside, Menidia estor. The improved growth with increasing dietary protein content in the current study was associated with increased feed consumption and protein intake by the fish. Although 35\% dietary crude protein gave the best growth, the optimum protein requirement was not established because no growth plateau was found. Generally, fish reach a plateau and subsequently show decreased weight gain when dietary protein levels reach and exceed their requirements

Composition [\%] of the experimental diets containing 20\%, 25\%, 30\%, and $35 \%$ crude protein

Table 1 (CP20, CP25, CP30 and CP35, respectively)

\begin{tabular}{|c|c|c|c|c|c|}
\hline \multirow{2}{*}{ Componen } & & \multicolumn{4}{|c|}{ Experimental diet } \\
\hline & & CP20 & CP25 & CP30 & CP35 \\
\hline \multirow{10}{*}{ 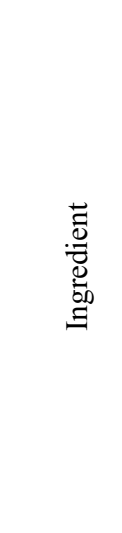 } & Yellow maize $^{1}$ & 48.19 & 38.72 & 29.26 & 19.78 \\
\hline & Groundnut cake ${ }^{2}$ & 19.21 & 28.24 & 37.24 & 46.27 \\
\hline & Fish meal $^{3}$ & 7.69 & 11.29 & 14.90 & 18.51 \\
\hline & Rice bran ${ }^{4}$ & 16.06 & 12.90 & 9.75 & 6.59 \\
\hline & Groundnut oil ${ }^{5}$ & 5.00 & 5.00 & 5.00 & 5.00 \\
\hline & Bone meal ${ }^{6}$ & 2.50 & 2.50 & 2.50 & 2.50 \\
\hline & Oyster shell ${ }^{7}$ & 0.50 & 0.50 & 0.50 & 0.50 \\
\hline & Vitamin premix ${ }^{8}$ & 0.60 & 0.60 & 0.60 & 0.60 \\
\hline & Table salt ${ }^{9}$ & 0.25 & 0.25 & 0.25 & 0.25 \\
\hline & TOTAL & 100.00 & 100.00 & 100.00 & 100.00 \\
\hline \multirow{4}{*}{ 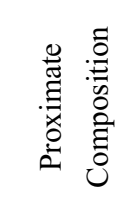 } & Crude protein & 20.85 & 25.70 & 30.80 & 35.80 \\
\hline & Crude lipid & 10.85 & 11.20 & 11.60 & 11.90 \\
\hline & Total ash & 9.90 & 10.70 & 11.50 & 12.35 \\
\hline & Crude fiber & 7.40 & 6.50 & 5.70 & 4.80 \\
\hline
\end{tabular}

1-4, 6-8 Ladokun Feed Mill Ltd., Ibadan, Oyo State, Nigeria. ${ }^{5,9}$ Ficon Supermarket, Ibadan, Oyo State, Nigeria.

Table 2

Growth responses and feed utilization parameters of juvenile Chrysichthys nigrodigitatus fed experimental diets containing $20 \%, 25 \%, 30 \%$, and $35 \%$ crude protein (CP20, $\mathrm{CP} 25, \mathrm{CP} 30$, and $\mathrm{CP} 35$, respectively)

\begin{tabular}{lcccc}
\hline \multirow{2}{*}{ Parameter } & \multicolumn{4}{c}{ Experimental diet } \\
\cline { 2 - 5 } & \multicolumn{1}{c}{ CP20 } & CP25 & CP30 & CP35 \\
\hline Initial weight [g] & $21.36 \pm 0.54$ & $21.30 \pm 0.43$ & $21.38 \pm 0.70$ & $21.26 \pm 0.56$ \\
Final weight [g] & $28.21 \pm 0.53^{\mathrm{a}}$ & $32.54 \pm 0.39^{\mathrm{b}}$ & $35.67 \pm 0.81^{\mathrm{c}}$ & $40.03 \pm 1.02^{\mathrm{d}}$ \\
Weight gain [\%] & $32.1 \pm 0.9^{\mathrm{a}}$ & $52.8 \pm 2.7^{\mathrm{b}}$ & $67.0 \pm 9.3^{\mathrm{c}}$ & $88.3 \pm 0.2^{\mathrm{d}}$ \\
Specific growth rate (SGR) [\%BW/day] & $0.50 \pm 0.04^{\mathrm{a}}$ & $0.76 \pm 0.03^{\mathrm{b}}$ & $0.91 \pm 0.06^{\mathrm{c}}$ & $1.13 \pm 0.02^{\mathrm{d}}$ \\
Total feed consumed (TFC) [g] & $39.06 \pm 0.50^{\mathrm{a}}$ & $41.23 \pm 0.16^{\mathrm{b}}$ & $45.42 \pm 0.81^{\mathrm{c}}$ & $48.73 \pm 1.02^{\mathrm{d}}$ \\
Feed conversion ratio (FCR) & $5.70 \pm 0.06^{\mathrm{d}}$ & $3.67 \pm 0.12^{\mathrm{c}}$ & $3.20 \pm 0.28^{\mathrm{b}}$ & $2.60 \pm 0.12^{\mathrm{a}}$ \\
Protein intake (PI) [g] & $7.81 \pm 0.10^{\mathrm{a}}$ & $10.31 \pm 0.42^{\mathrm{b}}$ & $13.63 \pm 0.24^{\mathrm{c}}$ & $17.06 \pm 0.35^{\mathrm{d}}$ \\
Protein efficiency ratio (PER) & $0.87 \pm 0.01^{\mathrm{a}}$ & $1.09 \pm 0.04^{\mathrm{b}}$ & $1.04 \pm 0.10^{\mathrm{b}}$ & $1.10 \pm 0.05^{\mathrm{b}}$ \\
\hline
\end{tabular}

Values are mean of 3 replicates $\pm \mathrm{SD}$; values within a row having different superscript letters are significantly different at $P<0.05$ 
(Anonymous 1993). However, the protein level of 35\% is within the range reported for the optimum protein requirement for juveniles of other omnivorous fish species (Anonymous 1993), including various species of catfish (see Introduction). Generally, protein requirements vary with species, size, quality of protein, water temperature and non-protein energy sources (Craig and Helfrich 2002). In this study, the requirement for protein may have been lower if dietary lipid allowed protein sparing for growth. Further research is needed to determine the actual protein requirement of this species by increasing the protein and lipid contents of the diets.

The observation that feed conversion ratio (FCR) decreased with increasing dietary protein levels has also been reported for many other species, irrespective of culture conditions, including Mozambique tilapia (Jauncey 1982), channel catfish (Lovell 1973), African catfish (Degani et al. 1989), pike perch, Sander lucioperca, (see: Schulz et al. (2007), and Mexican silverside (Martínez-Palacios et al. 2007). The high values observed (2.60-5.70) may be a result of the cheap, locally available feed ingredients used for practical diet formulation; high FCR values have been reported for a number of fish species fed on practical diets using locally available feed ingredients (Khan et al. 1993)

The effects of dietary protein level on PER differ among species (Dabrowski 1979, Martínez-Palacios et al. 2007). The fact that PER was not affected by dietary protein level in the current study except with $20 \% \mathrm{CP}$ indicates that all the other tested protein levels were used efficiently. This is in agreement with earlier studies with gilthead seabream, Sparus aurata (see: Robaina et al. 1997), European sea bass, Dicentrarchus labrax (see: Ballestrazzi et al. 1994), juvenile haddock (see: Kim et al. 2001), spotted sand bass, Paralabrax maculatofasciatus (see: Alvarez-González et al. 2001), and Mexican silverside (Martínez-Palacios et al. (2007). Other studies found that PER declined with increasing dietary protein in rabbitfish, Siganus guttatus (see: Parazo 1990), gilthead seabream (Santinha et al. 1996), olive flounder (Kim et al. 2002), and pike perch (Schulz et al. 2007). The opposite trend, that PER increases with increasing protein levels, has been observed in puffer fish
Fugu rubripes (see: Kanazawa et al. 1980), red drum, Sciaenops ocellatus (see: Daniels and Robinson 1986, Serrano et al. 1992), and olive flounder (see: Kikuchi et al. 1992, Lee et al. 2000).

Initial whole-body proximate composition in the present study was higher in moisture and lower in lipid compared with the final values. These results show that gross body composition was influenced by the experimental diets, as also found for other fish species (e.g., Shearer 1994, Martínez-Palacios et al. 1996, Ng et al. 2001, Schulz et al. 2007). However, in similar studies, Lazo et al. (1998) and Alvarez-González et al. (2001) found that dietary protein level had no significant effects on proximate body composition in Florida pompano, Trachinotus carolinus, and spotted sand bass, respectively. A non-significant trend for increasing whole-body protein levels with increasing dietary protein levels, as observed in the current study, has also been reported for other species (e.g., Degani et al. 1989, $\mathrm{Ng}$ et al. 2001). Khan et al. (1993), however, reported that the whole-body protein content of the Asian red tail catfish increased significantly with increasing dietary protein levels up to $42 \%$ and then decreased when fish were fed with higher protein levels. Generally, there has been no consistent trend concerning the effects of dietary protein levels on fish body protein content.

Whole-body lipid levels typically decrease with increasing dietary protein levels in fish ( $\mathrm{Ng}$ et al. 2001, Schulz et al. 2007), but the opposite effect was found in the current study. Although the same amount of groundnut oil was added to each of the diets as the lipid source, proximate analysis of the diets showed that their lipid content increased with protein content, such that the CP35 diet had 10\% higher lipid content than the CP20 diet. This likely contributed to the observed increase in whole-body lipid levels with increasing dietary protein. As well, this can be attributed to the nature of this species, being a fatty fish, to deaminate and store excess dietary protein as lipid. Khan et al. (1993) reported the same effect in Asian red tail catfish. The inverse relationship between body moisture and lipid is consistent with other reports, regardless of fish species (e.g., Jauncey 1982, $\mathrm{Ng}$ et al. 2001).

Table 3

Whole-body chemical composition [\%] of juvenile Chrysichthys nigrodigitatus fed experimental diets containing 20\%, 25\%,30\%, and 35\% crude protein (CP20, CP25, CP30, and CP35, respectively)

\begin{tabular}{lccccc}
\hline \multirow{2}{*}{ Parameter } & Initial values & \multicolumn{4}{c}{ Experimental diet } \\
\cline { 3 - 6 } & & \multicolumn{1}{c}{ CP20 } & \multicolumn{1}{c}{ CP25 } & \multicolumn{1}{c}{ CP30 } & CP35 \\
\hline Crude protein & $68.45 \pm 0.20$ & $68.50 \pm 0.20$ & $68.64 \pm 0.19$ & $68.84 \pm 0.21$ & $68.95 \pm 0.24$ \\
Crude lipid & $9.34 \pm 0.07^{\mathrm{a}}$ & $9.92 \pm 0.20^{\mathrm{b}}$ & $10.21 \pm 0.20^{\mathrm{c}}$ & $11.38 \pm 0.05^{\mathrm{d}}$ & $12.48 \pm 0.09^{\mathrm{e}}$ \\
Moisture & $10.01 \pm 0.07^{\mathrm{c}}$ & $9.31 \pm 0.06^{\mathrm{d}}$ & $8.00 \pm 0.05^{\mathrm{c}}$ & $7.69 \pm 0.04^{\mathrm{b}}$ & $7.00 \pm 0.03^{\mathrm{a}}$ \\
Ash & $11.13 \pm 0.37^{\mathrm{c}}$ & $11.00 \pm 0.09^{\mathrm{c}}$ & $11.36 \pm 0.33^{\mathrm{c}}$ & $10.37 \pm 0.05^{\mathrm{a}}$ & $10.54 \pm 0.23^{\mathrm{b}}$ \\
Crude fiber & $0.82 \pm 0.002$ & $0.64 \pm 0.005$ & $0.91 \pm 0.004$ & $0.89 \pm 0.006$ & $0.65 \pm 0.003$ \\
Carbohydrate & $0.025 \pm 0.006^{\mathrm{a}}$ & $0.63 \pm 0.004^{\mathrm{c}}$ & $0.60 \pm 0.004^{\mathrm{c}}$ & $0.83 \pm 0.005^{\mathrm{d}}$ & $0.38 \pm 0.003^{\mathrm{b}}$ \\
\hline
\end{tabular}

Values are means $\pm \mathrm{SD}$; values within a row having different superscript letters are significantly different at $P<0.05$. 
In conclusion, the use of a practical diet containing at least $35 \%$ protein is appropriate for growth and nutrient utilization of juvenile of Chrysichthys nigrodigitatus under the conditions of the present study.

\section{ACKNOWLEDGEMENTS}

We thank Prof. S.O. Fagade for his contributions and advice towards the success of this work.

\section{REFERENCES}

Adebayo O.T., Quadri K. 2005. Dietary protein level and feeding rate for hybrid clariid catfish, Clarias gariepinus $\times$ Heterobranchus bidorsalis, in homestead tanks. Journal of Applied Aquaculture 17: 97-106. DOI: 10.1300/J028v17n01_08.

Adewolu M.A., Fagade S.O. 1996. Protein requirements of Chrysichthys nigrodigitatus (Lacepede) fingerlings. Nigerian Journal of Science 30: 97-103.

Afinowi M.A., Marioghae I.E. 1987. Summary of aquaculture activities in Nigeria. Pp. 83-89. In: Powles H. (ed.) Research Priorities for African Aquaculture (Report of a Workshop held in Dakar, Senegal, October 13-16, 1986). IDRC Manuscript Report 149. International Development Research Centre, Ottawa.

Alvarez-González C.A., Civera-Cerecedo R., Ortiz-Galindo J.L., Dumas S., Moreno-Legorreta M., Grayeb-Del Alamo T. 2001. Effect of dietary protein level on growth and body composition of juvenile spotted sand bass, Paralabrax maculatofasciatus, fed practical diets. Aquaculture 194: 151-159. DOI: 10.1016/S0044-8486(00)00512-3.

Anonymous 1976. Nutrient requirement of warm water fishes. NRC (National Research Council). National Academy of Science, Washington.

Anonymous 1990. Official Methods of Analysis. 15th edn. Association of Official Analytical Chemists, Washington.

Anonymous 1993. Nutrient requirements of fish. NRC (National Research Council). National Academy Press, Washington.

Arowosoge I.A. 1987. Nutritional implications of cottonseed meal in the diets of Clarias lazera $(\mathrm{C} \& \mathrm{~V})$. Ph.D. Thesis, University of Ibadan, Nigeria.

Ballestrazzi R., Lanari D., D’Agaro E., Mion A. 1994. The effect of dietary protein level and source on growth, body composition, total ammonia and reactive phosphate excretion of growing sea bass (Dicentrarchus labrax). Aquaculture 127: 197-206. DOI: 10.1016/0044-8486(94)90426-X.

Bekcan S., Dogankaya L., Cakirogullari, G.C. 2006. Growth and body composition of European catfish (Silurus glanis L.) fed diets containing different percentages of protein. The Israeli Journal of Aquaculture-Bamidgeh 58: 137-142.

Craig S., Helfrich L.A. 2002. Understanding fish nutrition, feeds, and feeding. Virginia Cooperative Extension Publication No. 420-256.

Dabrowski K. 1979. Feeding requirements of fish with particular attention to common carp. A review. Polish Archives of Hydrobiology 26: 135-158.

Dahlgren B.T. 1979. The effects of population density on fecundity and fertility in the guppy, Poecilia reticulata
(Peters). Journal of Fish Biology 15: 71-91. DOI: 10.1111/j.1095-8649.1979.tb03573.x.

D’Abramo L.R., Hanson T.R., Steeby J.A. 2008. Production and associated economics of channel catfish fed different practical diets in the fingerling-stocker phase of culture. North American Journal of Aquaculture 70: 154-161. DOI: 10.1577/A06-085.1.

Daniels W.H., Robinson E.H. 1986. Protein and energy requirements of juvenile red drum (Sciaenops ocellatus). Aquaculture 53: 243-252. DOI: 10.1016/0044-8486(86)90354-6.

Degani G., Ben-Zvi Y., Levanon D. 1989. The effect of different protein levels and temperatures on the feed utilization, growth and body composition of Clarias gariepinus (Burchell 1822). Aquaculture 76: 293-301. DOI: 10.1016/00448486(89)90082-3 is there a comma between Burchel and the year? (no comma according to the internet abstract).

Ezenwa B.I.O. 1982a. On the economics of the production of the catfish Chrysichthys nigrodigitatus in brackish water ponds in Nigeria. Pp. 81-99. In: Coche A.G. (ed.) Coastal Aquaculture: Development Perspectives in Africa and Case Studies from Other Regions. Committee for Inland Fisheries of Africa Technical Paper 9. United Nations Food and Agriculture Organization, Rome.

Ezenwa B.I.O. 1982b. Production of catfish Chrysichthys nigrodigitatus in Nigeria using groundnut cake as supplemental feed. Aquaculture 27: 197-203. DOI: 10.1016/0044-8486(82)90057-6.

Garling D.L.jr., Wilson R.P. 1976. Optimum dietary protein to energy ratio for channel catfish fingerlings, Ictalurus punctatus. Journal of Nutrition 106: 1368-1375.

Gaylord T.G., Gatlin D.M. 2001. Dietary protein and energy modifications to maximize compensatory growth of channel catfish (Ictalurus punctatus). Aquaculture 194: 337-348. DOI: 10.1016/S0044-8486(00)00523-8.

Gohl B.O. 1985. Tropical Feeds, 2nd edn. United Nations Food and Agriculture Organization, Rome.

Ibrahim K.H. 1988. Aquaculture research in Africa. Pp. 109-120. In: King H.R., Ibrahim K.H. (eds.) Village Level Aquaculture Development in Africa (Proceedings of the Commonwealth Consultative Workshop on Village Level Aquaculture in Africa held in Freetown, Sierra Leone, 14-20 February 1985). Commonwealth Secretariat, London.

Jauncey K. 1982. The effects of varying dietary protein level on growth, food conversion, protein utilization and body composition of juvenile tilapias (Sarotherodon mossabicus). Aquaculture 27: 43-54. DOI: 10.1016/0044-8486(82)90108-9.

Kanazawa A., Teshima S., Sakamoto M., Shinomiya A. 1980. Nutritional requirements of the puffer fish: a purified test diet and the optimum protein level. Bulletin of the Japanese Society of Scientific Fisheries 46: 1357-1361.

Khan S., Ang K.J., Ambak M.A. 1996. The effect of varying dietary protein level on the growth, food conversion, protein utilization and body composition of tropical catfish Mystus nemurus (C. \& V.) cultured in static pond water system. Aquaculture Research 27: 823-829. DOI: 10.1111/j.1365-2109.1996.tb01241.x. 
Khan M.S., Ang K.J., Ambak M.A., Saad C.R. 1993. Optimum dietary protein requirement of a Malaysian freshwater catfish, Mystus nemurus. Aquaculture 112: 227-235. DOI: 10.1016/0044-8486(93)90448-8.

Kikuchi K., Honda H., Kiyono M. 1992. Effect of dietary protein level on growth and body composition of Japanese flounder, Paralichthys olivaceus. Suisanzoshoku 40: 335-340. [In Japanese with English abstract.]

Kim J.-D., Lall S.P. 2001. Effects of dietary protein level on growth and utilization of protein and energy by juvenile haddock (Melanogrammus aeglefinus). Aquaculture 195: 311-319. DOI: 10.1016/S0044-8486(00)00562-7.

Kim J.D., Lall S.P., Milley J.E. 2001. Dietary protein requirements of juvenile haddock (Melanogrammus aeglefinus L.). Aquaculture Research 32 (Suppl. 1): 1-7. DOI: 10.1046/j.1355-557x.2001.00001.x.

Kim K.W., Wang X.J., Bai S.C. 2002. Optimum dietary protein level for maximum growth of juvenile olive flounder Paralichthys olivaceus (Temminck et Schlegel). Aquaculture Research 33: 673-679. DOI: 10.1046/j.1365$-2109.2002 .00704 . x$.

Lazo J.P., Davis D.A., Arnold C.R. 1998. The effects of dietary protein level on growth, feed efficiency and survival of juvenile Florida pompano (Trachinotus carolinus). Aquaculture 169: 225-232. DOI: 10.1016/S0044-8486(98)00384-6.

Lee S.-M., Cho S.H., Kim K.-D. 2000. Effects of dietary protein and energy levels on growth and body composition of juvenile flounder Paralichthys olivaceus. Journal of the World Aquaculture Society 31: 306-315. DOI: 10.1111/j.1749-7345.2000.tb00882.x.

Li M.H., Bosworth B.G., Robinson E.H. 2000. Effect of dietary protein concentration on growth and processing yield of channel catfish Ictalurus punctatus. Journal of the World Aquaculture Society 31: 592-598. DOI: 10.1111/j.1749-7345.2000.tb00908.x.

Li M.H., Manning B.B., Robinson E.H., Bosworth B.G. 2003. Effect of dietary protein concentration and stocking density on production characteristics of pond-raised channel catfish Ictalurus punctatus. Journal of the World Aquaculture Society 34: 147-155. DOI: 10.1111/j.1749-7345.2003.tb00051.x.

Li M.H., Robinson E.H., Bosworth B.G. 2007. Effects of dietary protein concentration and L-carnitine on growth, processing yield, and body composition of channel catfish $\times$ blue catfish $F_{1}$ hybrids. North American Journal of Aquaculture 69: 229-234. DOI: 10.1577/A06-049.1.

Lovell R.T. 1973. Protein requirement of cage-cultured channel catfish. Pp. 357-361. In: Mitchell A.L. (ed.) Proceedings of the 26th Annual Conference of the Southeastern Association of Game and Fish Commissioners, 22-25 October 1972; Knoxville, Tennessee.

Martínez-Palacios C.A., Harfush-Melendez M., ChávezSánchez C., Ross L.G. 1996. The optimum dietary protein level for the Mexican cichlid Cichlasoma urophthalmus (Günther): a comparison of estimates derived from experiments using fixed-rate and satiation feeding. Aquaculture Nutrition 2: 11-20. DOI: $10.1111 /$ j.1365-2095.1996.tb00003.x.
Martínez-Palacios C.A., Ríos-Durán M.G., AmbrizCervantes L., Jauncey K.J., Ross L.G. 2007. Dietary protein requirement of juvenile Mexican silverside (Menidia estor Jordan 1879), a stomachless zooplanktophagous fish. Aquaculture Nutrition 13: 304-310. DOI: $10.1111 /$ j.1365-2095.2007.00479.x. Is there a comma between Jordan and the year? (no comma according to the internet abstract).

Maynard L., Loosili J., Hintz H. 1979. Animal Nutrition 7th edn. Mc Graw Hill, New York.

Meyer G., Fracalossi D.M. 2004. Protein requirement of jundia fingerlings, Rhamdia quelen, at two dietary energy concentrations. Aquaculture 240: 331-343. DOI: 10.1016/ /j.aquaculture.2004.01.034.

Ng W.-K., Keembiyehetty C.N., Wilson R.P. 1998. Bioavailability of niacin from feed ingredients commonly used in feeds for channel catfish, Ictalurus punctatus. Aquaculture 161: 393-404. DOI: 10.1016/S0044-8486(97)00287-1.

Ng W.-K., Soon S.-C., Hashim R. 2001. The dietary protein requirement of a bagrid catfish, Mystus nemurus (Cuvier \& Valenciennes), determined using semipurified diets of varying protein level. Aquaculture Nutrition 7: 45-51. DOI: 10.1046/j.1365-2095.2001.00160.x.

Omar E.A. 1996. Optimum dietary protein level and stocking density for catfish (Clarias lazera) fingerlings in concrete ponds. Journal of Animal Physiology and Animal Nutrition 76: 122-131. DOI: 10.1111/j.1439-0396.1996.tb00682.x.

Parazo M.M. 1990. Effect of dietary protein and energy level on growth, protein utilization and carcass composition of rabbitfish, Siganus guttatus Aquaculture 86: 41-49. DOI: 10.1016/0044-8486(90)90220-H.

Robaina L., Moyano F.J., Izquierdo M.S., Socorro J., Vergara J.M., Montero D. 1997. Corn glutten and meat and bone meals as protein sources in diets for gilthead seabream (Sparus aurata): Nutritional and biological implications. Aquaculture 157: 347-359. DOI: 10.1016/S0044-8486(97)00174-9.

Robinson E.H., Li M.H. 1998. Comparison of practical diets with and without animal protein at various concentrations of dietary protein on performance of channel catfish Ictalurus punctatus raised in earthen ponds. Journal of the World Aquaculture Society 29: 273-280. DOI: 10.1111/j.1749-7345.1998.tb00647.x.

Robinson E.H., Li M.H. 1999. Evaluation of practical diets with various levels of dietary protein and animal protein for pond-raised channel catfish Ictalurus punctatus. Journal of the World Aquaculture Society 30: 147-153. DOI: 10.1111/j.1749-7345.1999.tb00861.x.

Santinha P.J.M., Gomes E.F.S., Coimbra J.O. 1996. Effects of protein level of the diet on digestibility and growth of gilthead sea bream, Sparus auratus L. Aquaculture Nutrition 2: 81-87. DOI: 10.1111/j.1365-2095.1996.tb00012.x.

Schulz C., Böhm M., Wirth M., Rennert B. 2007. Effect of dietary protein on growth, feed conversion, body composition and survival of pike perch fingerlings (Sander lucioperca) Aquaculture Nutrition 13: 373-380. DOI: 10.1111/j.1365-2095.2007.00487.x. 
Serrano J.A., Nematipour G.R., Gatlin D.M.III 1992. Dietary protein requirement of the red drum (Sciaenops ocellatus) and relative use of dietary carbohydrate and lipid. Aquaculture 101: 283-291. DOI: 10.1016/0044-8486(92)90031-F.

Shearer K.D. 1994. Factors affecting the proximate composition of cultured fishes with emphasis on salmonids. Aquaculture 119: 63-88. DOI:10.1016/0044-8486(94)90444-8.
Viveen W.A.R., Richter C.J.J., van Oordt P.G.W.J., Janssen J.A.L., Huisman E.A. 1986. Practical manual for the culture of the African catfish (Clarias gariepinus). Ministry of Foreign Affairs Cooperation, The Hague.

Received: 15 July 2008

Accepted: 6 July 2009

Published electronically: 10 December 2009 